\title{
Tunable thermoplastic poly(ester-urethane)s based on modified serinol extenders
}

\author{
Ruairí P. Brannigan ${ }^{a}$, Anthony Walder ${ }^{b}$, Andrew P. Dove ${ }^{a^{*}}$ \\ a Department of Chemistry, University of Warwick, Gibbet Hill Road, Coventry, CV4 7AL, \\ United Kingdom.
}

${ }^{\mathrm{b}}$ The Lubrizol Corporation, 207 Lowell Street, Wilmington, MA, 0887, USA.

\section{SUPPLEMENTARY INFORMATION}

\section{EXPERIMENTAL}

Materials

Tetrahydrofuran (THF), ethyl acetate, methanol, diethyl ether, dimethylsulfoxide (DMSO), sodium carbonate, sodium hydroxide and magnesium sulfate were purchased from Fischer Scientific. 2-Amino-1,3-propanediol, ethyl chloroformate, ethyl isocyanate and 1,8diazabicyclo[5.4.0]undec-7-ene (DBU) were purchased from from Sigma Aldrich. Poly(عcaprolactone) (PCL) was obtained from Perstorp $\left(\mathrm{CAPA}^{\mathrm{TM}} 2201 \mathrm{~A}, M_{\mathrm{w}}=2,000 \mathrm{~g} / \mathrm{mol}\right.$, hydroxyl number $=54-58)$. Dicyclohexylmethane 4,4'-Diisocyanate $\left(\mathrm{H}_{12} \mathrm{MDI}\right)$ was purchased from Tokyo Chemicals Industry Co. Ltd. and was distilled and stored under inert conditions. All chemicals were used as received unless otherwise stated. 
Instrumental methods and general considerations

${ }^{1} \mathrm{H}$ and ${ }^{13} \mathrm{C}$ NMR spectra were obtained on a Bruker DPX-400 spectrometer $(400 \mathrm{MHz})$ at 293 K. All chemical shifts were reported as $\delta$ in parts per million (ppm) and referenced to the residual solvent signal $\left(\left(\mathrm{CD}_{3}\right)_{2} \mathrm{SO}:{ }^{1} \mathrm{H}, \delta=2.50 \mathrm{ppm} ;{ }^{13} \mathrm{C}, \delta=39.52\right)$. Gel permeation chromatography (GPC) was used to determine the dispersities $\left(\bigoplus_{M}\right)$ and molecular weights of synthesized polymers. GPC was conducted in dimethylformamide (DMF) using a Varian PLGPC 50 system equipped with $2 \times$ PLgel $5 \mu \mathrm{M}$ MIXED-D columns in series and a differential refractive index (RI) detector at a flow rate of $1.0 \mathrm{~mL} \mathrm{~min}^{-1}$. The systems were calibrated against Varian Polymer Laboratories Easi-Vial linear poly(methyl methacrylate) (PMMA) and analyzed by the software package Cirrus v3.3. Tensile data was obtained at ambient temperature by axially loading 'dog-bones' in a Tensiometric M100-1CT system with a load cell capacity of $1 \mathrm{kN}$ and crosshead speed of $5 \mathrm{~mm} \mathrm{~min}^{-1}$ with a premeasured grip-to-grip separation All values reported were obtained from an average of 10 repeat specimens and the results were recorded using winTest v4.3.2 software. Molten polymer samples were molded into 'dog-bones' via compression molding at $100{ }^{\circ} \mathrm{C}$ using a PTFE mold and allowed to cool to ambient temperature. Static contact angle measurements were obtained using a KRUSS DSA10 drop shape analyzer and were processed using the software package DSA3 1.72b IEEE1394b. Each polymer was dissolved in minimal DMSO before being deposited as a thin film on a glass slide. The solvent was allowed to evaporate overnight before trace solvent was removed in vacuo. TPEU samples were allowed to anneal at $25{ }^{\circ} \mathrm{C}$ in an incubator for 5 days prior to analysis. Using a KRUSS DSA100 a $100 \mu \mathrm{L}$ droplet of DI $\mathrm{H} 2 \mathrm{O}$ was deposited onto the surface of the film and the measurement was taken immediately and analyzed using a sessile drop type with a polynomial (tangent 2) computational method. Dynamic mechanical thermal analysis (DMTA) data was obtained using a Mettler Toledo DMA 1 star system and was analyzed using the software package 
STARe V13.00a (build 6917). DMTA samples were analyzed by single cantilever bending, oscillating at a frequency of 5.0 and $0.5 \mathrm{MHz}$ with a displacement of $10 \mathrm{~mm}$ between -80 and $180{ }^{\circ} \mathrm{C}$ at a heating rate of $2{ }^{\circ} \mathrm{C}$ min-1. All polymers were analyzed using a Mettler Toledo DMA 1 Star system to determine the thermo-mechanical properties and glass transitions of the materials. Polymer samples were molded into 'bars' via compression molding using a PTFE mold and allowed to cool to ambient temperature. All TPEUs were annealed for 5 days in an incubator at $25^{\circ} \mathrm{C}$. Wide angle x-ray diffraction data was obtained using a Panalytical X'Pert Pro MPD equipped with a $\mathrm{Cu} \mathrm{K} \alpha_{1}$ hybrid monochromator $(\lambda=0.154 \mathrm{~nm})$ as the incident beam optics and PiXcel detector was processed using OriginPro 8 software. Accelerated degradation studies were conducted under conditions previously reported by $\mathrm{C} \mathrm{X}$ F Lam et al. ${ }^{1}$ All polymers which could form 'degradation disks' were subjected to accelerated degradation studies $(5 \mathrm{M}$ aq. $\mathrm{NaOH})$. Polymer samples were molded into disks via compression molding at $100{ }^{\circ} \mathrm{C}$ using a PTFE mold and allowed to cool to ambient temperature. The disks were placed in individual vials containing $20 \mathrm{~mL}$ of $5 \mathrm{M} \mathrm{NaOH}$ solution and incubated at $37{ }^{\circ} \mathrm{C}$. The weight of the dried disks was measured periodically using an analytical balance.

\section{General synthesis of protected 2-amino-diol extenders}

Carbamate-protected $\left(\mathrm{C}_{3 \mathrm{c}}\right)$ : The carbamate-protected 2-amino-1,3-propanediol extender $\left(\mathrm{C}_{3 \mathrm{c}}\right)$ was synthesized according to literature. ${ }^{2}$ In a $1 \mathrm{~L}$ round bottom flask fitted with a magnetic stirrer bar, 2-amino-1,3-propanediol $\left(10 \mathrm{~g}, 1.10 \times 10^{-1} \mathrm{~mol}\right)$ and $\mathrm{Na}_{2} \mathrm{CO}_{3}\left(25 \mathrm{~g}, 2.36 \times 10^{-1}\right.$ mol) were dissolved in a mixture of deionized $\mathrm{H}_{2} \mathrm{O}$ :THF $(500 \mathrm{~mL}, 2: 1$ respectively). The solution was cooled on an ice-bath for $20 \mathrm{~min}$ before the addition of ethyl chloroformate $\left(10.25 \mathrm{~mL}, 1.07 \times 10^{-1} \mathrm{~mol}\right)$ and allowed to stir for $2 \mathrm{~h}$. The reaction mixture was removed from the ice-bath and allowed to warm to room temperature and was stirred overnight $(\sim 12$ 
h). The desired product was extracted with ethyl acetate $(6 \times 300 \mathrm{~mL})$, dried over $\mathrm{MgSO}_{4}$ and filtered before all volatiles were removed in vacuo to yield an off white crystalline solid. The solid was sublimed to yield the pure product as a white crystalline solid. (15.07 g, yield 84\%). Characterizing data was consistent with the previous report. ${ }^{2}{ }^{1} \mathrm{H}$ NMR (400 MHz, DMSO- $\left.d_{6}\right)$ $\delta 6.62\left(\mathrm{~d},{ }^{3} J_{\mathrm{H}-\mathrm{H}}=7.1 \mathrm{~Hz}, 1 \mathrm{H}\right), 4.54\left(\mathrm{t},{ }^{3} J_{\mathrm{H}-\mathrm{H}}=5.3 \mathrm{~Hz}, 2 \mathrm{H}\right), 3.97\left(\mathrm{q},{ }^{3} J_{\mathrm{H}-\mathrm{H}}=7.0 \mathrm{~Hz}, 2 \mathrm{H}\right), 3.50-$ $3.28(\mathrm{~m}, 6 \mathrm{H}), 1.15\left(\mathrm{t},{ }^{3} J_{\mathrm{H}-\mathrm{H}}=7.1 \mathrm{~Hz}, 3 \mathrm{H}\right) .{ }^{13} \mathrm{C}$ NMR (101 MHz, DMSO-d $\left.d_{6}\right): \delta 157.34(\mathrm{~s}$, $\mathrm{C}=\mathrm{O}), 62.10\left(\mathrm{~s}, \mathrm{CH}_{2}\right), 61.60(\mathrm{~s}, \mathrm{CH}), 54.1\left(\mathrm{~s}, \mathrm{CH}_{2}\right), 14.60\left(\mathrm{~s}, \mathrm{CH}_{3}\right)$.

Urea-protected $\left(\mathrm{C}_{3 \mathrm{u}}\right)$ : The urea-protected 2-amino-1,3-propanediol extender $\left(\mathrm{C}_{3 \mathrm{u}}\right)$ was synthesized according to literature. ${ }^{3}$ In a 1 L round bottom flask fitted with a magnetic stirrer bar, 2-amino-1,3-propanediol (10 g, $\left.1.10 \times 10^{-1} \mathrm{~mol}\right)$ was dissolved in a mixture of methanol:THF (500 mL, 1:2 respectively). The solution was cooled on an ice-bath for $20 \mathrm{~min}$ before the addition of ethyl isocyanate $\left(8.69 \mathrm{~mL}, 1.10 \times 10^{-1} \mathrm{~mol}\right)$ and allowed to stir for 15min. The reaction mixture was removed from the ice-bath and allowed to warm to room temperature and was stirred for $4 \mathrm{~h}$. The solvent was removed in vacuo and the white offwhite solid was suspended and stirred in $400 \mathrm{~mL}$ of diethyl ether for 20 min before being collected by filtration. The white crystalline solid was dried in vacuo to yield the pure ureaprotected extender as a fluffy white solid. (16.04 g, yield 90\%). Characterizing data was consistent with the previous report. ${ }^{3}{ }^{1} \mathrm{H}$ NMR $\left(400 \mathrm{MHz}, \mathrm{DMSO}-d_{6}\right) \delta 5.98\left(\mathrm{t},{ }^{3} J_{\mathrm{H}-\mathrm{H}}=5.5 \mathrm{~Hz}\right.$, $1 \mathrm{H}), 5.64\left(\mathrm{~d},{ }^{3} J_{\mathrm{H}-\mathrm{H}}=7.8 \mathrm{~Hz}, 1 \mathrm{H}\right), 4.64\left(\mathrm{t},{ }^{3} J_{\mathrm{H}-\mathrm{H}}=5.3 \mathrm{~Hz}, 2 \mathrm{H}\right), 3.55-3.45(\mathrm{~m}, 1 \mathrm{H}), 3.44-$ $3.27(\mathrm{~m}, 4 \mathrm{H}), 3.05-2.93(\mathrm{~m}, 2 \mathrm{H}), 0.97\left(\mathrm{t},{ }^{3} \mathrm{~J}_{\mathrm{H}-\mathrm{H}}=7.2 \mathrm{~Hz}, 3 \mathrm{H}\right) .{ }^{13} \mathrm{C}$ NMR (101 MHz, DMSO$\left.d_{6}\right) \delta 157.85(\mathrm{~s}, \mathrm{C}=\mathrm{O}), 60.47\left(\mathrm{~s}, \mathrm{CH}_{2}\right), 52.64(\mathrm{~s}, \mathrm{CH}), 33.92\left(\mathrm{~s}, \mathrm{CH}_{2}\right), 15.63\left(\mathrm{~s}, \mathrm{CH}_{3}\right)$.

\section{General synthesis of TPUs from carbamate-protected extenders}

The TPU synthesis described is based on the synthesis of a polyurethane with a $30 \%$ hardblock composition using the $\mathrm{C}_{3 \mathrm{c}}$ extender. 
In a clean and dry vial fitted with a magnetic stirrer bar, poly( $\varepsilon$-caprolactone $)$ with a $M_{\mathrm{W}}=$ $2,000 \mathrm{~g} \mathrm{~mol}^{-1}\left(\mathrm{PCL}_{2 \mathrm{k}}\right)\left(1 \mathrm{~g}, 5 \times 10^{-4} \mathrm{~mol}\right)$ and $\mathrm{DBU}\left(3.73 \mu \mathrm{L}, 6.9 \times 10^{-6} \mathrm{~mol}\right)$ were heated to $100{ }^{\circ} \mathrm{C}$ under a flow $\mathrm{N}_{2}$ for 20 min to aid the reduction of water within the system. The molten mixture was cooled to $80{ }^{\circ} \mathrm{C}$ before the addition of $\mathrm{H}_{12} \mathrm{MDI}\left(402 \mu \mathrm{L}, 1.64 \times 10^{-3} \mathrm{~mol}\right)$. The reaction mixture was allowed to stir under $\mathrm{N}_{2}$ for $40 \mathrm{~min}$ to allow for prepolymer formation before the addition of the $C_{3 c}$ extender $\left(186 \mathrm{mg}, 1.14 \times 10^{-3} \mathrm{~mol}\right)$. The polymerization was allowed to proceed for $2 \mathrm{~h}$ before being removed from the heat to retard further reaction. The molecular weight was analyzed via GPC and the unreacted isocyanate was quenched by washing the TPU in methanol before being dried in vacuo. ${ }^{1} \mathrm{H}$ NMR (400 MHz, DMSO-d $\left.d_{6}\right) \delta 7.22-6.64(\mathrm{~m}, 1 \mathrm{H}), 4.08-3.72(\mathrm{~m}, 8 \mathrm{H}), 3.55-3.01(\mathrm{~m}, 3 \mathrm{H}), 2.27(\mathrm{t}, \mathrm{J}=$ $7.2 \mathrm{~Hz}, 5 \mathrm{H}), 1.92-0.66(\mathrm{~m}, 27 \mathrm{H}) . M_{\mathrm{n}}=110.5 \mathrm{~kg} \cdot \mathrm{mol}^{-1}, \bigoplus_{\mathrm{M}}=1.98$ (RI detection, DMF GPC).

\section{General synthesis of TPUs from urea-protected $C_{3}$ extenders}

The TPU synthesis described is based on the synthesis of a polyurethane with a $30 \%$ hardblock composition using the $\mathrm{C}_{3 \mathrm{u}}$ extender.

In a clean and dry vial fitted with a magnetic stirrer bar, poly( $\varepsilon$-caprolactone $)$ with a $M_{\mathrm{W}}=$ $2,000 \mathrm{~g} \mathrm{~mol}^{-1}\left(\mathrm{PCL}_{2 \mathrm{k}}\right)\left(1 \mathrm{~g}, 5 \times 10^{-4} \mathrm{~mol}\right)$ and DBU $\left(3.73 \mu \mathrm{L}, 6.9 \times 10^{-6} \mathrm{~mol}\right)$ were heated to $100{ }^{\circ} \mathrm{C}$ under a flow $\mathrm{N}_{2}$ for $20 \mathrm{~min}$ to aid the reduction of water within the system. The molten mixture was cooled to $80{ }^{\circ} \mathrm{C}$ before the addition of $\mathrm{H}_{12} \mathrm{MDI}\left(402 \mu \mathrm{L}, 1.64 \times 10^{-3} \mathrm{~mol}\right)$. The reaction mixture was allowed to stir under $\mathrm{N}_{2}$ for $40 \mathrm{~min}$ to allow for prepolymer formation before the addition of a solution of $\mathrm{C}_{3 \mathrm{u}}$ extender $\left(185 \mathrm{mg}, 1.14 \times 10^{-3} \mathrm{~mol}\right)$ dissolved in 150 $\mu \mathrm{L}$ of DMSO. The polymerization was allowed to proceed for $2 \mathrm{~h}$ before being removed from the heat to retard further reaction. The molecular weight was analyzed by GPC and any 
unreacted isocyanate using IR spectroscopy, was quenched by washing the TPU in $50 \mathrm{~mL}$ of methanol before being dried in vacuo. $\quad{ }^{1} \mathrm{H}$ NMR (400 MHz, DMSO- $\left.d_{6}\right) \delta 6.04-5.67$ (m, $2 \mathrm{H}), 4.11-3.80(\mathrm{~m}, 19 \mathrm{H}), 3.53-2.89(\mathrm{~m}, 23 \mathrm{H}), 2.27(\mathrm{~m}, 14 \mathrm{H}), 1.91-0.69(\mathrm{~m}, 79 \mathrm{H}) . M_{\mathrm{n}}=$ $100.9 \mathrm{~kg} \cdot \mathrm{mol}^{-1}, \bigoplus_{\mathrm{M}}=2.10$ (RI detection, DMF GPC).

\section{Tensiometric analysis}

All TPUs were analyzed using an M100-1CT tensiometer to determine the tensile properties of the materials. Molten polymer samples were molded into 'dog-bones' via compression molding at $200{ }^{\circ} \mathrm{C}$ using a PTFE mold and allowed to cool to ambient temperature. All TPUs were annealed for 5 days in an incubator at $25^{\circ} \mathrm{C}$. The rate of elongation of each sample was $5 \mathrm{~mm} \mathrm{~min}^{-1}$. Data was collected from ten repeats.

\section{Wide-angle $x$-ray diffraction}

Wide angle x-ray diffraction data was obtained using a Panalytical X'Pert Pro MPD equipped with a $\mathrm{Cu} \mathrm{K} \alpha_{1}$ hybrid monochromator $(\lambda=0.154 \mathrm{~nm})$ as the incident beam optics and PiXcel detector was processed using OriginPro 8 software. Each polymer was compression molded into discs and allowed to anneal for 5 days in an incubator at $25^{\circ} \mathrm{C}$ before standard "powder" $2 \theta-\theta$ diffraction scans were carried out at room temperature in the angular range between $5^{\circ}$ and $60^{\circ} 2 \theta$.

Dynamic mechanical and thermal analysis (DMTA)

Dynamic mechanical thermal analysis (DMTA) data was obtained using a Mettler Toledo DMA 1 star system and was analyzed using the software package STARe V13.00a (build 6917). DMTA samples were analyzed by single cantilever bending, oscillating at a frequency of 5.0 and $0.5 \mathrm{MHz}$ with a displacement of $10 \mathrm{~mm}$ between -80 and $180{ }^{\circ} \mathrm{C}$ at a heating rate 
of $2{ }^{\circ} \mathrm{C} \min ^{-1}$. All polymers were analyzed using a Mettler Toledo DMA 1 Star system to determine the thermo-mechanical properties and glass transitions of the materials. Molten polymer samples were molded into 'bars' via compression molding using a PTFE mold and allowed to cool to ambient temperature. All TPEUs were annealed for 5 days in an incubator at $25{ }^{\circ} \mathrm{C}$.

\section{Degradation studies}

Accelerated degradation studies were conducted under conditions previously reported by Lam et al. ${ }^{1}$ All TPUs were subjected to accelerated degradation studies (5 M aq. NaOH). Polymer samples were molded into disks via compression molding at $200{ }^{\circ} \mathrm{C}$ using a PTFE mold and allowed to cool to ambient temperature. The disks were placed in individual vials containing $20 \mathrm{~mL}$ of $5 \mathrm{M} \mathrm{NaOH}$ solution and incubated at $37{ }^{\circ} \mathrm{C}$ with constant agitation at 60

rpm. The surface of the disks were 'dab'-dried using KIMTECH SCIENCE ${ }^{\mathrm{TM}}$ precision wipes in order to remove excess surface water before the weight was measured periodically using an analytical balance.

\section{REFERENCES}

1. Lam, C. X.; Savalani, M. M.; Teoh, S. H.; Hutmacher, D. W. Biomed Mater 2008, 3, (3), 034108.

2. Venkataraman, S.; Veronica, N.; Voo, Z. X.; Hedrick, J. L.; Yang, Y. Y. Polym. Chem. 2013, 4, (10), 2945-8.

3. Oble, J.; Riflade, B.; Noel, A.; Malacria, M.; Thorimbert, S.; Hasenknopf, B.; Lacote, E. Org. Lett. 2011, 13, (22), 5990-5993. 


\section{FIGURES}
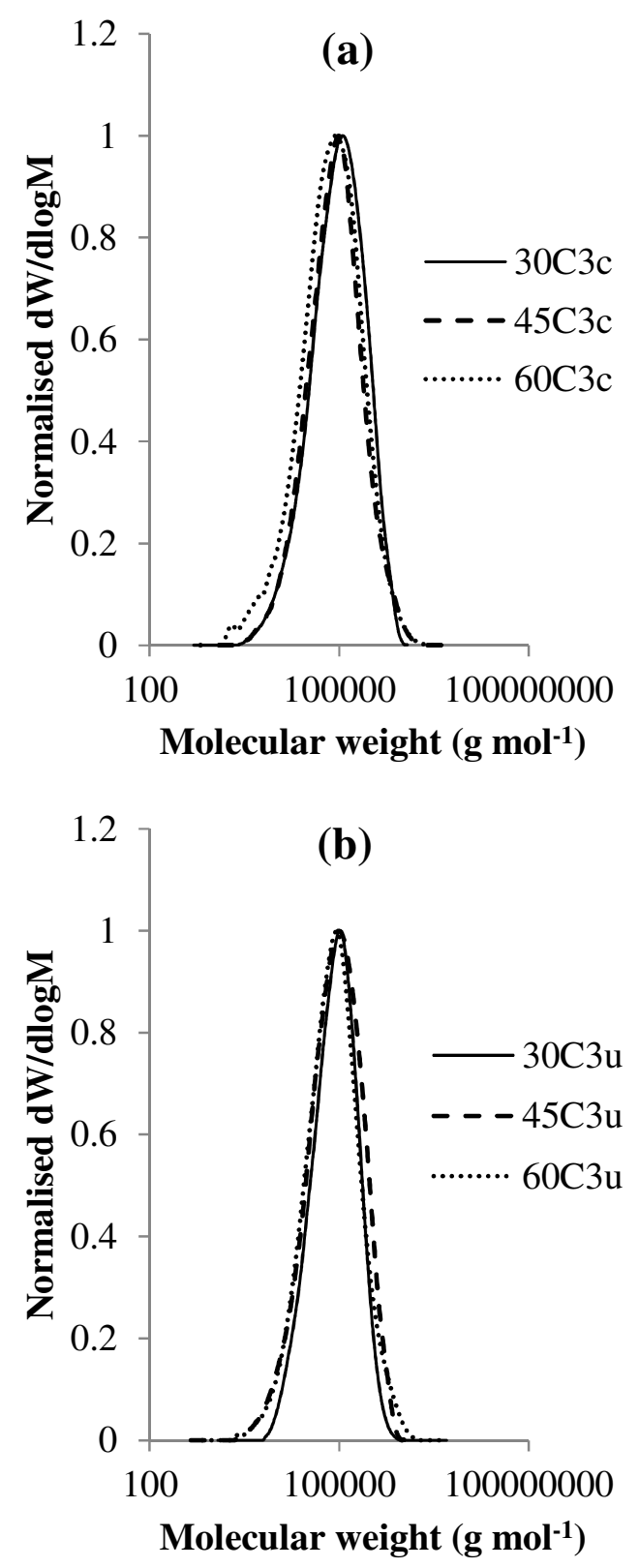

Figure S1. GPC chromatograms (RI detection) (a) $\mathrm{C}_{3 c}$ and (b) $\mathrm{C}_{3 \mathrm{u}}$-based TPEUs in DMF against poly(methyl metacrylate) (PMMA) standards (Table 1). 


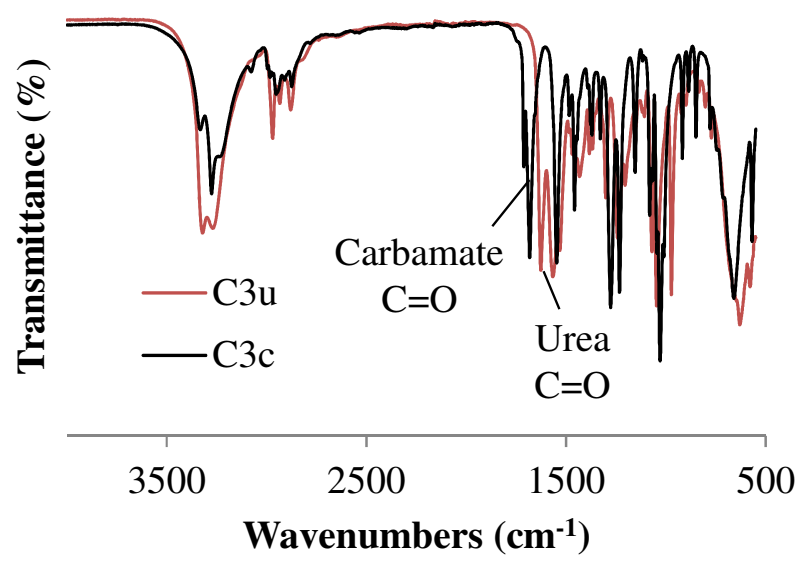

Figure S2.FT-IR spectra of $\mathrm{C}_{3 \mathrm{c}}\left(\right.$ black) and $\mathrm{C}_{3 \mathrm{u}}(\mathrm{red})$ extenders.

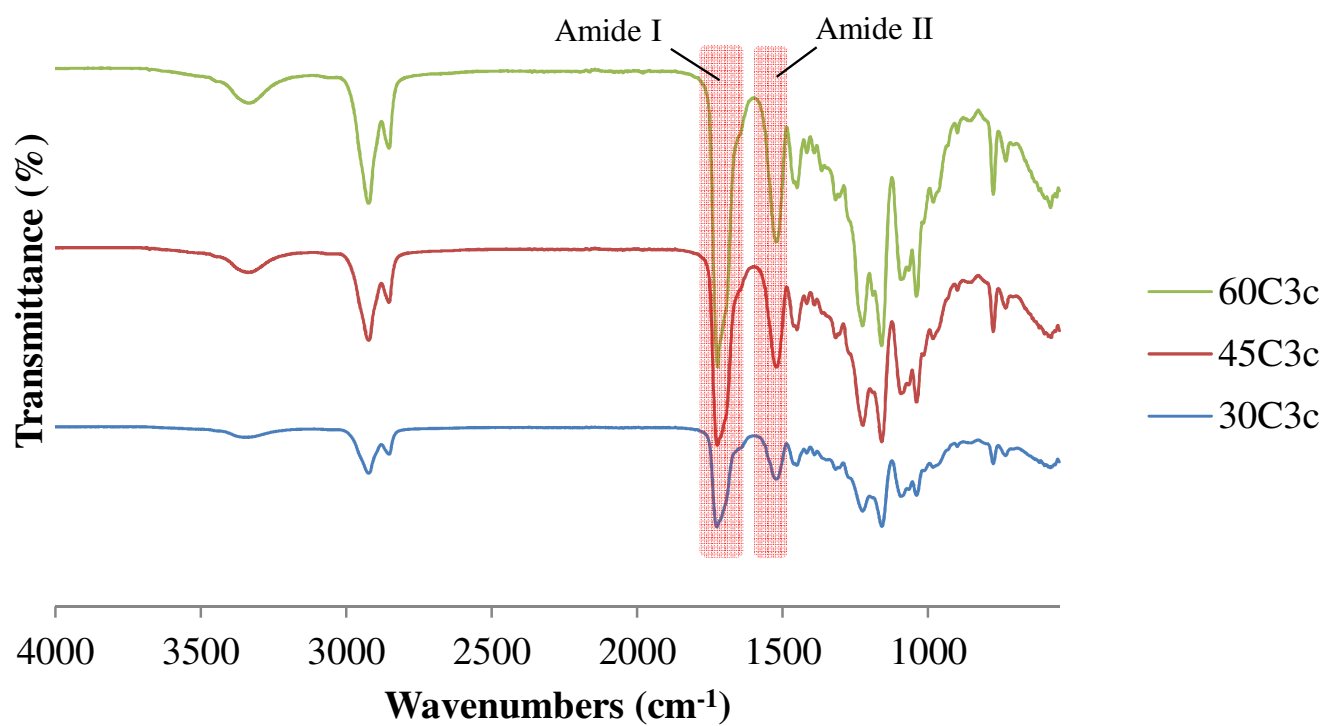

Figure S3. FT-IR spectra of $\mathrm{C}_{3 c}$-based TPEUs. 


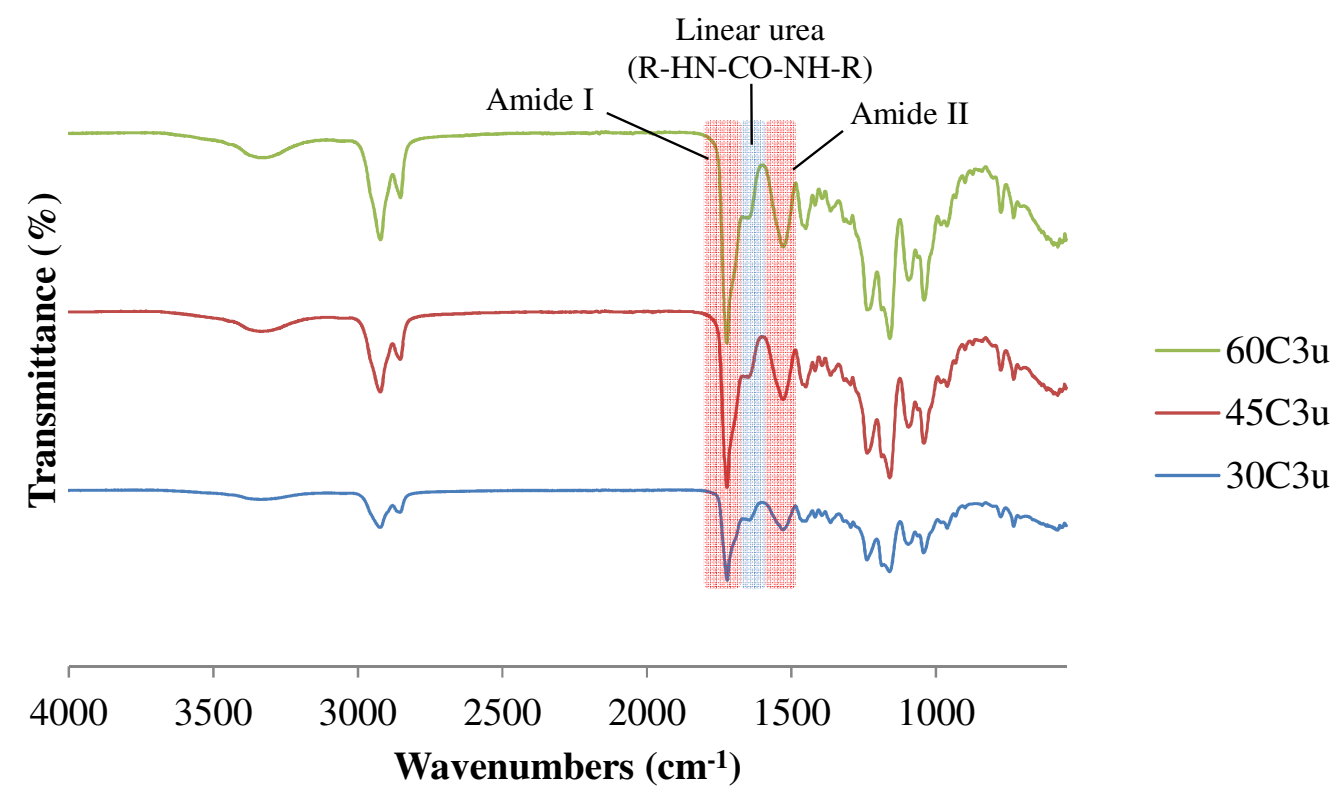

Figure S4. FT-IR spectra of $\mathrm{C}_{3 \mathrm{u}}$ TPEUs.

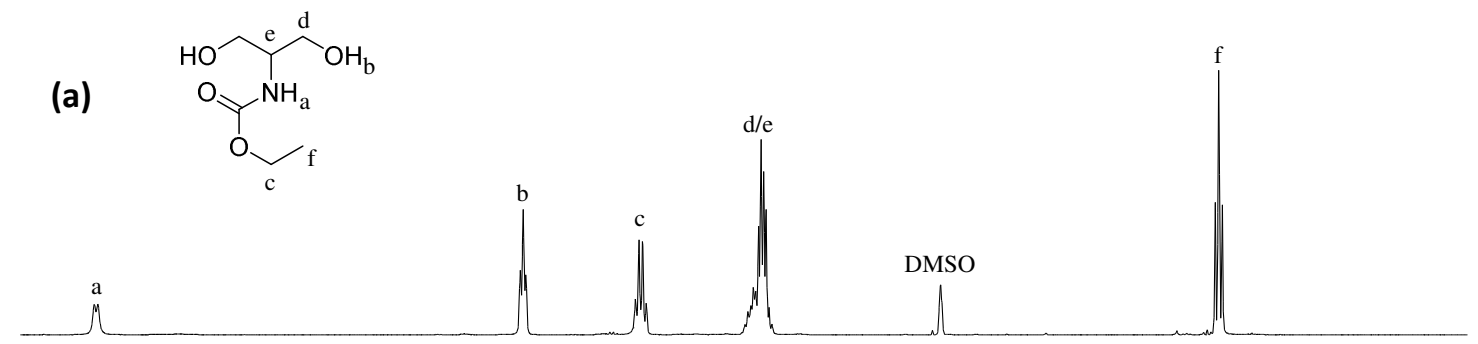

(b)<smiles>CCNC(=O)NC(CO)[C@H]([NH3+])CO</smiles>
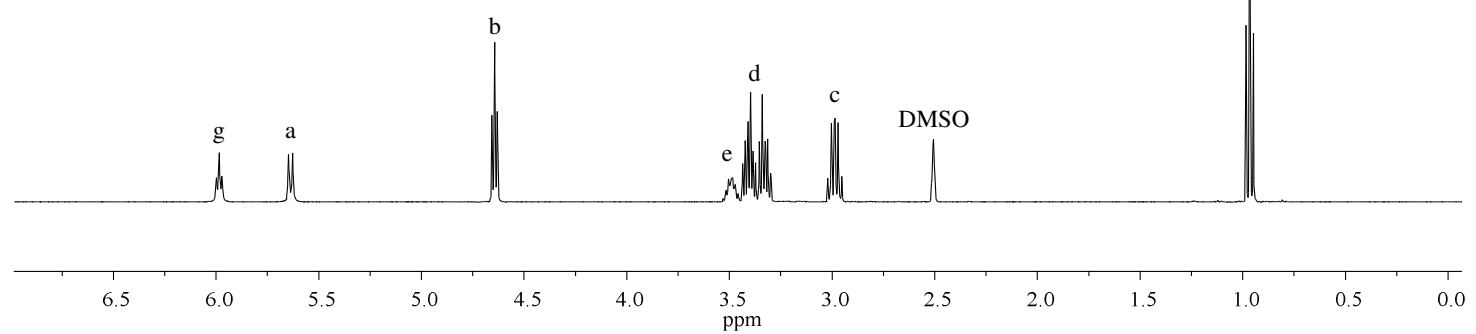

Figure S5. ${ }^{1} \mathrm{H}$ NMR spectra of (a) $\mathrm{C}_{3 \mathrm{c}}$ and (b) $\mathrm{C}_{3 \mathrm{u}}$ extenders $\left(400 \mathrm{MHz}, 25^{\circ} \mathrm{C}\right.$, DMSO- $d_{6}$ ). 


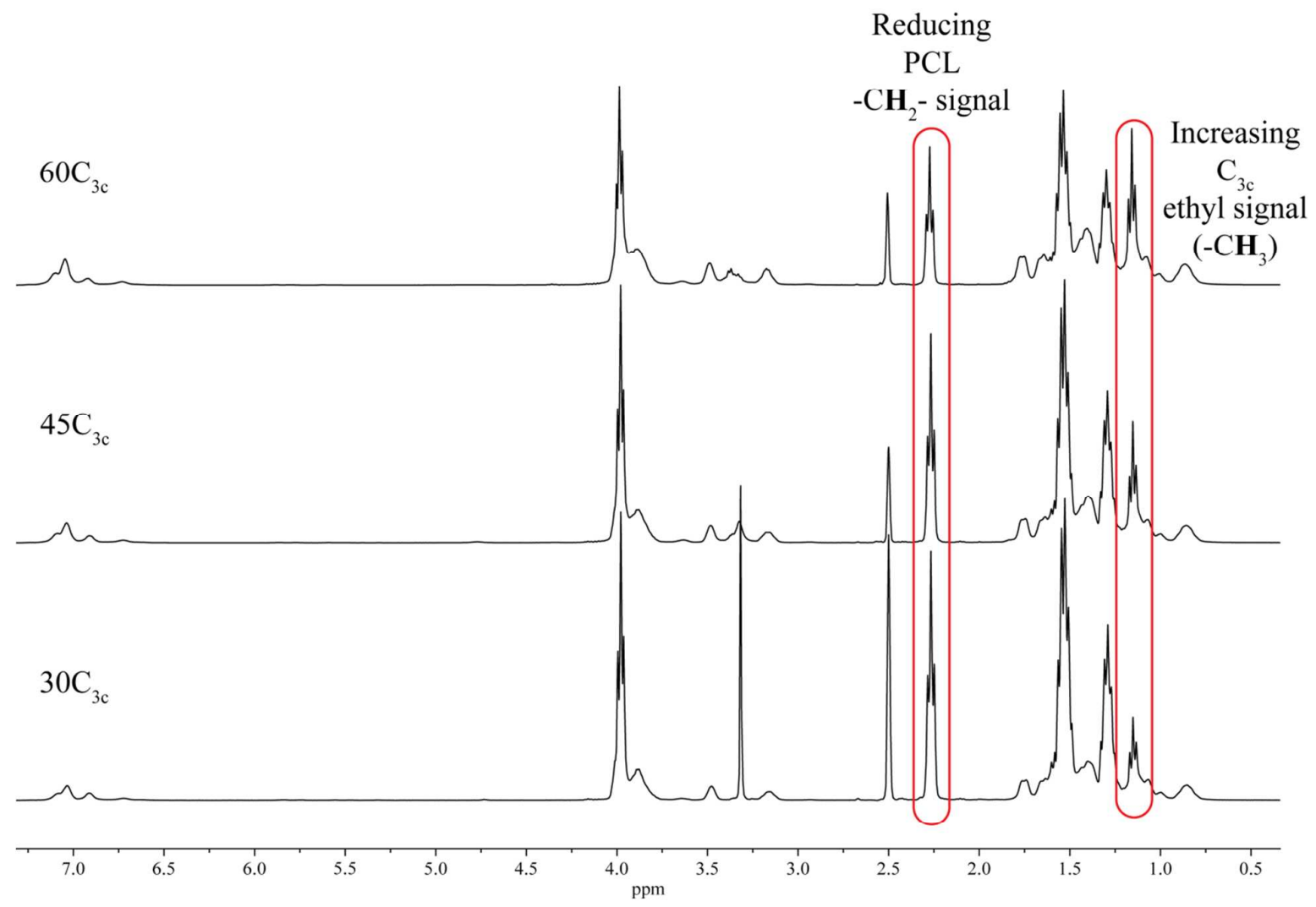

Figure S6. ${ }^{1} \mathrm{H}$ NMR spectra of $\mathrm{C}_{3 \mathrm{c}}$-based TPEUs (Table 1). (400 MHz, $25{ }^{\circ} \mathrm{C}$, DMSO- $d_{6}$ ). 


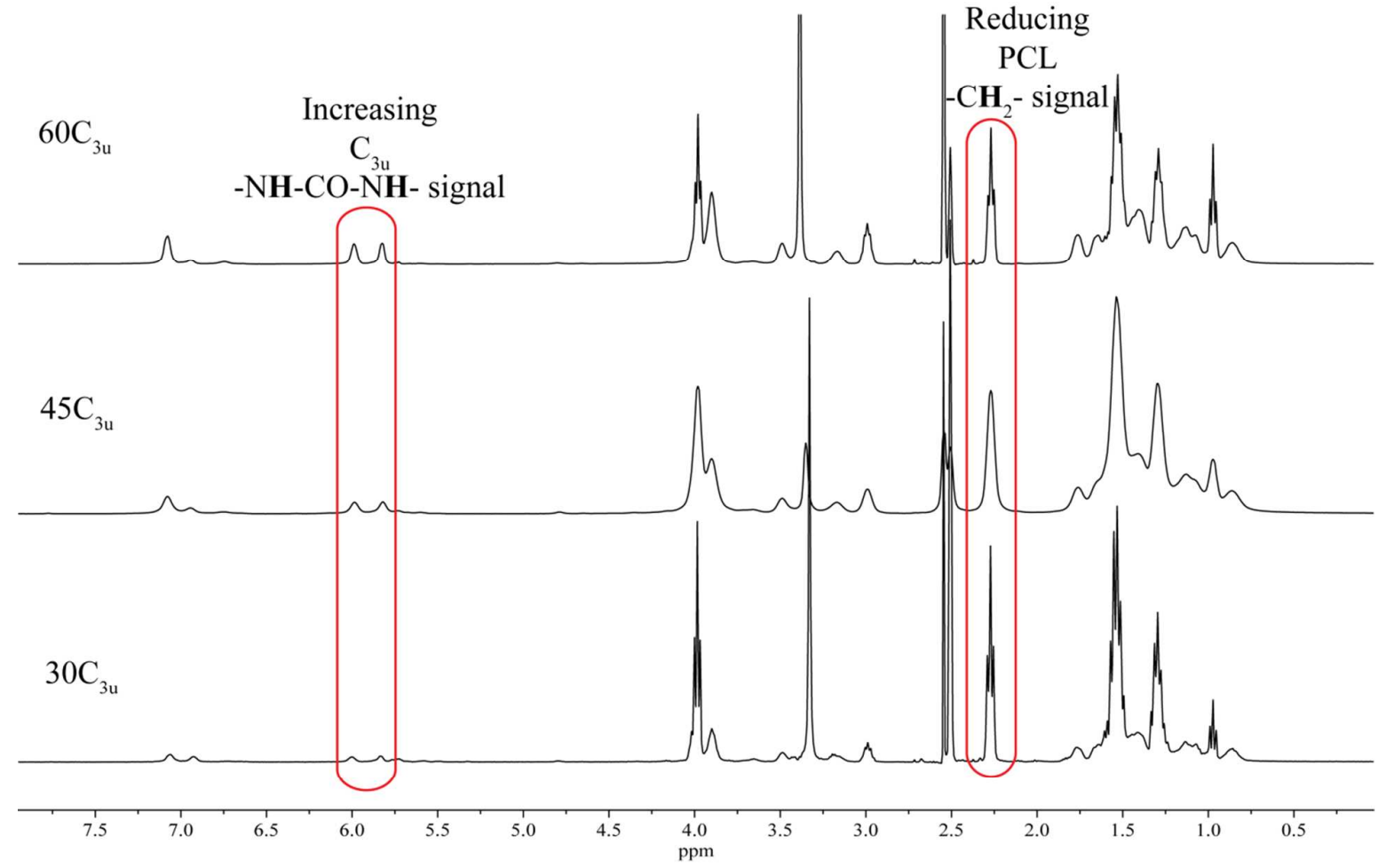

Figure S7. ${ }^{1} \mathrm{H}$ NMR spectra of $\mathrm{C}_{3 \mathrm{u}}$-based TPEUs (Table 1). (400 MHz, $25^{\circ} \mathrm{C}$, DMSO- $d_{6}$ ).

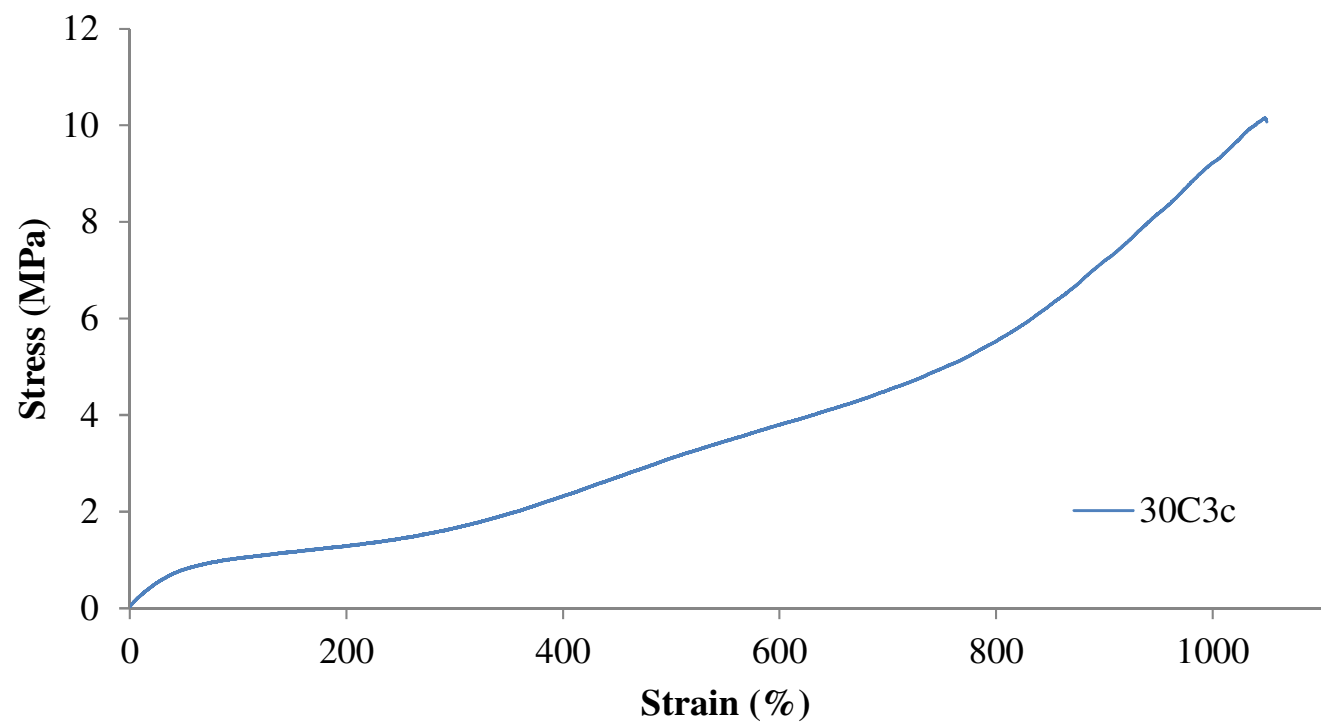

Figure S8. Exemplar stress-strain curves of $30 \mathrm{C}_{3 \mathrm{c}}$-TPEU (Table 2). Experiments were conducted at ambient temperature $\left(\sim 25^{\circ} \mathrm{C}\right)$ at an elongation rate of $5 \mathrm{~mm} \mathrm{~min}^{-1}$ until failure. 


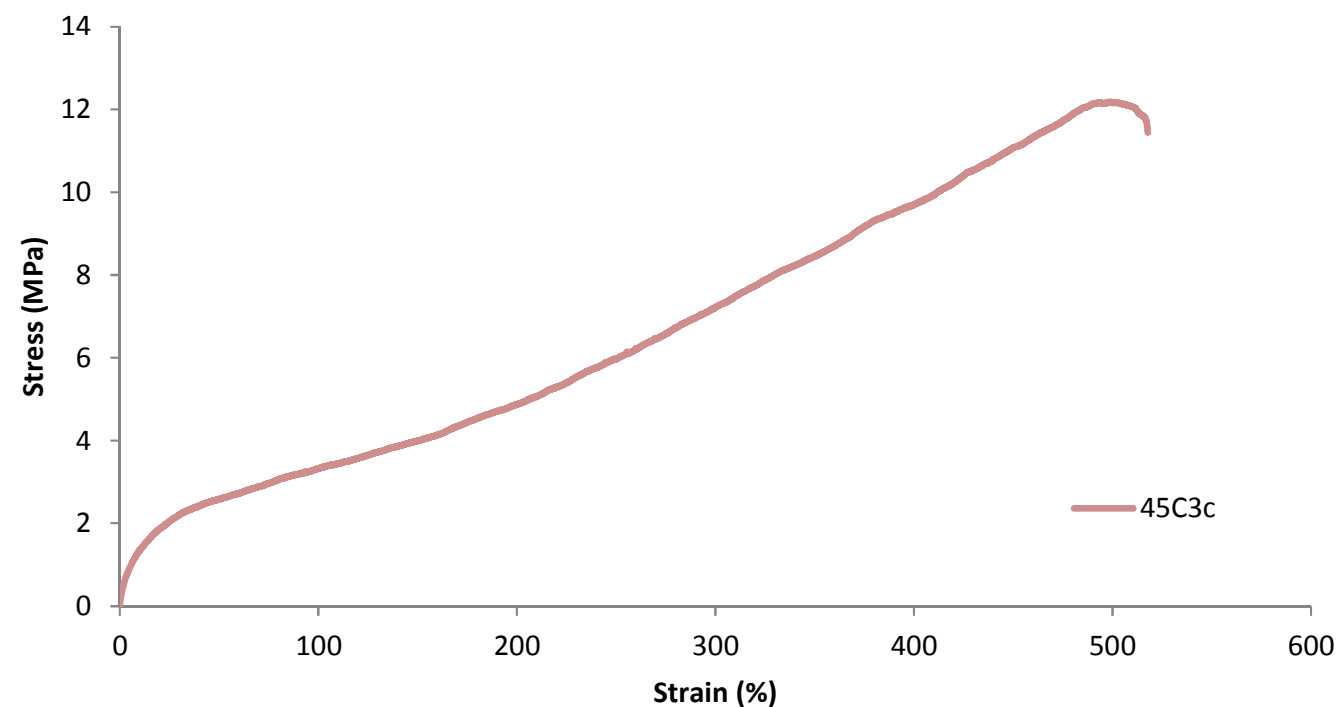

Figure S9. Exemplar stress-strain curves of $45 \mathrm{C}_{3 \mathrm{c}}$-TPEU (Table 2). Experiments were conducted at ambient temperature $\left(\sim 25^{\circ} \mathrm{C}\right)$ at an elongation rate of $5 \mathrm{~mm} \mathrm{~min} \mathrm{~m}^{-1}$ until failure.

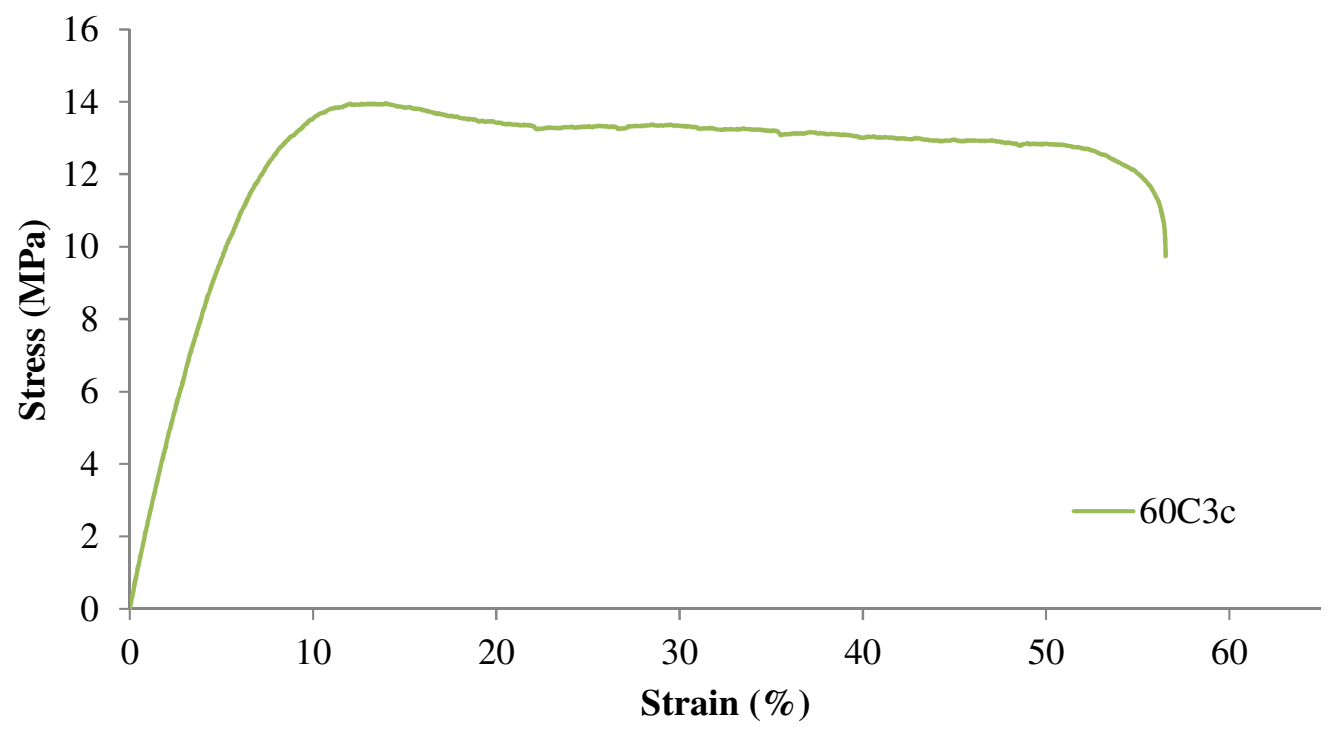

Figure S10. Exemplar stress-strain curves of $60 \mathrm{C}_{3 \mathrm{c}}$-TPEU (Table 2). Experiments were conducted at ambient temperature $\left(\sim 25^{\circ} \mathrm{C}\right)$ at an elongation rate of $5 \mathrm{~mm} \mathrm{~min}^{-1}$ until failure. 


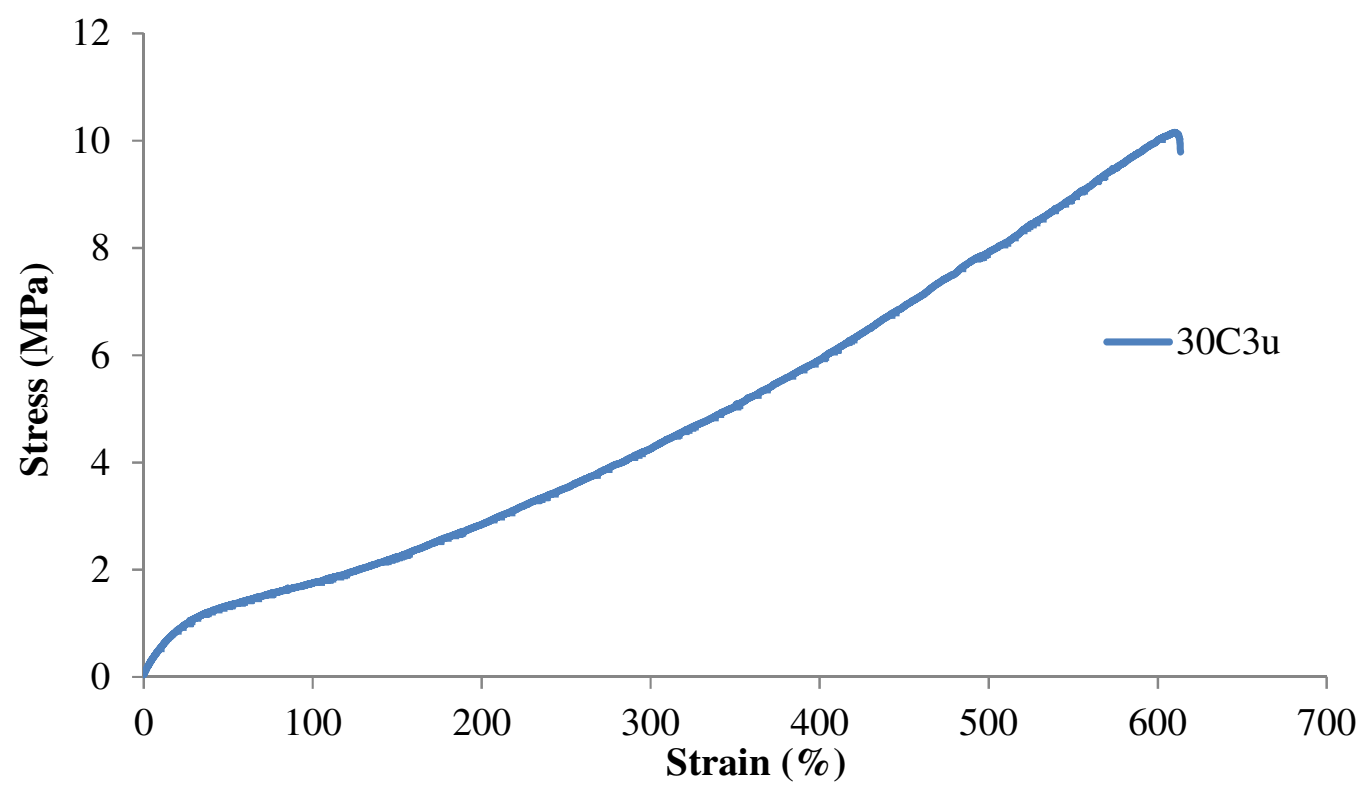

Figure S11. Exemplar stress-strain curves of $30 \mathrm{C}_{3 \mathrm{u}}$-TPEU (Table 2). Experiments were conducted at ambient temperature $\left(\sim 25^{\circ} \mathrm{C}\right)$ at an elongation rate of $5 \mathrm{~mm} \mathrm{~min} \mathrm{~m}^{-1}$ until failure.

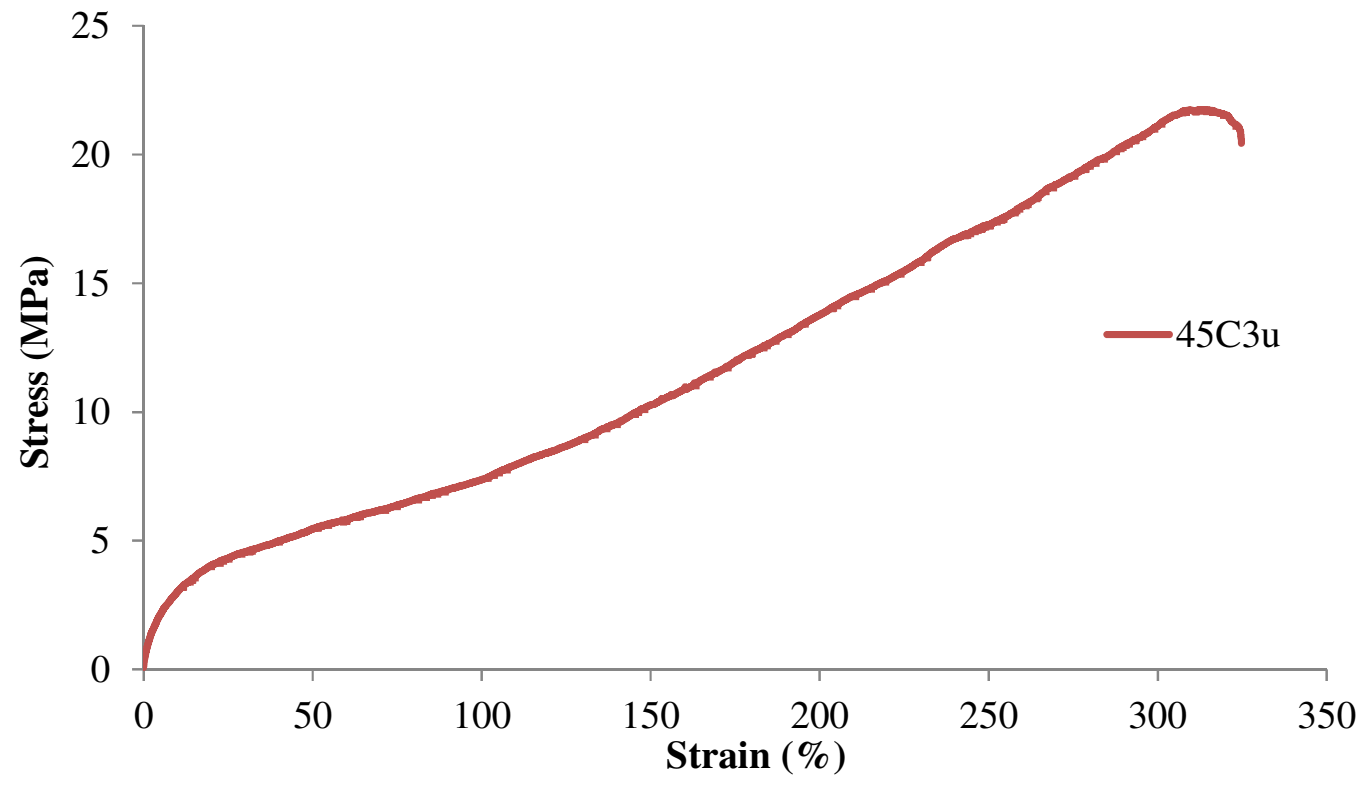

Figure S12. Exemplar stress-strain curves of $45 \mathrm{C}_{3 \mathrm{u}}$-TPEU (Table 2). Experiments were conducted at ambient temperature $\left(\sim 25^{\circ} \mathrm{C}\right)$ at an elongation rate of $5 \mathrm{~mm} \mathrm{~min}^{-1}$ until failure. 


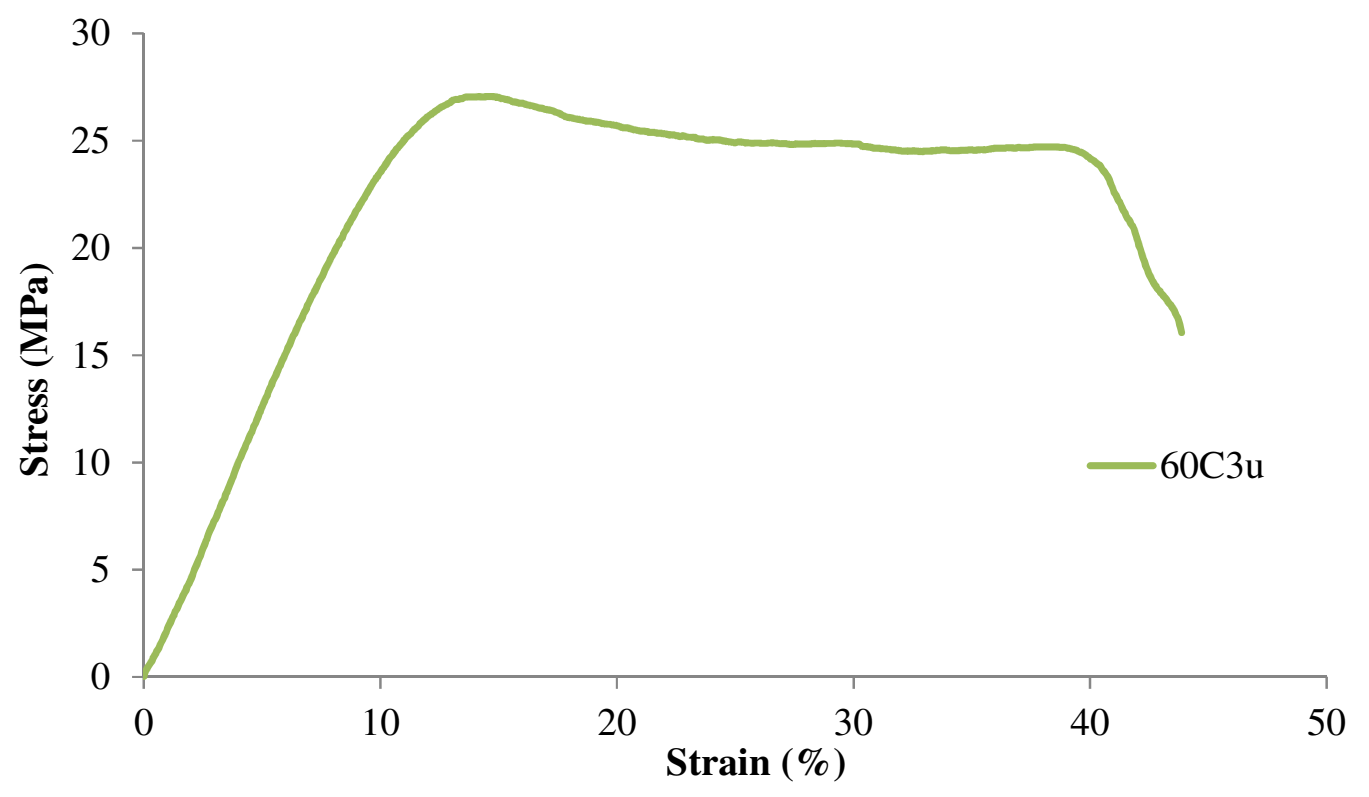

Figure S13. Exemplar stress-strain curves of $60 \mathrm{C}_{3 \mathrm{u}}$-TPEU (Table 2). Experiments were conducted at ambient temperature $\left(\sim 25^{\circ} \mathrm{C}\right)$ at an elongation rate of $5 \mathrm{~mm} \mathrm{~min} \mathrm{~m}^{-1}$ until failure.

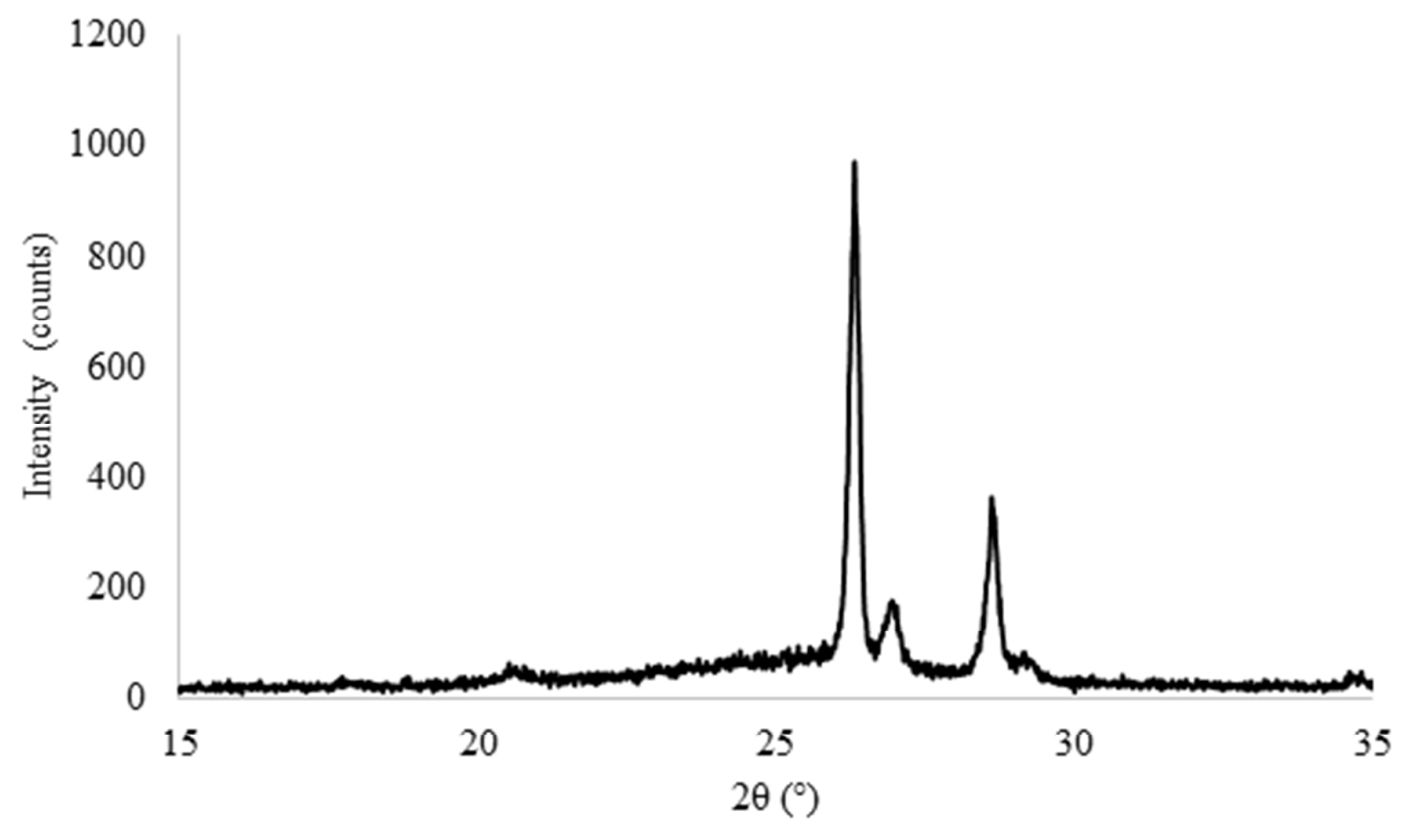

Figure S14. WAXD diffractograms for crystalline PCL $\left(M_{\mathrm{w}}=2,000 \mathrm{~g} \mathrm{~mol}^{-1}\right)$ 